\title{
Assessing The Macroeconomic Effects Of Water Scarcity In South Africa Using A Water-CGE Model
}

\section{Anne Briand}

University of Rouen

Arnaud Reynaud ( $\nabla$ arnaud.reynaud@tse-fr.eu )

Toulouse School of Economics https://orcid.org/0000-0002-5308-678X

Franck Viroleau

Sorbonne University: Sorbonne Universite

\section{Vasileos Markantonis}

GIZ: Deutsche Gesellschaft fur Internationale Zusammenarbeit GmbH

\section{Giuliana Branciforti}

GIZ: Deutsche Gesellschaft fur Internationale Zusammenarbeit GmbH

\section{Research Article}

Keywords: Computable general equilibrium model, South Africa, Water, Economic growth, Households, Firms

Posted Date: July 9th, 2021

DOI: https://doi.org/10.21203/rs.3.rs-495619/v1

License: (c) This work is licensed under a Creative Commons Attribution 4.0 International License. Read Full License 


\section{Abstract}

We develop a dynamic computable general equilibrium (CGE) model to assess the macroeconomic impacts of water scarcity and water (in)security in South Africa. The water-CGE model which includes a detailed representation of water flows (surface water, groundwater, wastewater, and seawater) has been calibrated with an updated social accounting matrix enabling to conduct policy simulations up to 2030. We show that water scarcity will have an impact on the South African economy. With an increase of water scarcity by $17 \%$, the CGE model predicts a decrease of South African GDP by $-0.34 \%$ in 2030 . The long-term impact of water scarcity varies from one sector to another, with the most negatively impacted sectors being those related to water (loss of GDP up to $-2.48 \%$ ). Due to the increase of water scarcity, the unemployment rate is expected to be $0.1 \%$ higher in 2020 which represents a loss of 18,000 jobs compared to the baseline year (2013). The $17 \%$ increase in water scarcity is also expected to have a negative impact on household welfare: by 2030 , household consumption may decrease by $-0.26 \%$. Some policies can mitigate the negative impacts of water scarcity, the most promising one being to promote water saving.

\section{Introduction}

South Africa is facing a water crisis due in particular to a lack of water-infrastructure maintenance and investment, and recurrent droughts driven by climatic variations. Water security is one of the most prominent challenges for South Africa's public authorities. According to the National Water and Sanitation Master Plan, the deficit between water supply and demand in South Africa could rise to between 2.7 and 3.8 billion $\mathrm{m}^{3}$ per year by 2030, if demand continues to grow at current levels. Such a deficit is equivalent to about $17 \%$ of available surface water and groundwater resources. Although the macroeconomic impacts of increased water scarcity by 2030 remain largely unknown, specific policies dedicated to mitigating them should be designed and implemented as soon as possible.

Establishing and quantifying how water scarcity impacts on economic growth and the wellbeing of population is challenging since it requires the development of complex macroeconomic models. Water is used in most economic activities and the allocation of water resources involves many economic agents (firms, households, government) and sectors with complex interactions. Computable General Equilibrium (CGE) models have proven to be a powerful tool to analyze the macroeconomic effects of public policies. However, the adaptation of these models to include use of water resources is still relatively undeveloped, possibly due to the limited availability of data related to water use and water costs that would provide the basis for calibrating a CGE model.

We propose here a dynamic CGE model focused on water for South Africa, and we show how such a model can provide valid recommendations for decision-making related to water policy. The CGE model considers all water users and sectors, while taking full account of macroeconomic constraints and intersectoral linkages. It includes a detailed representation of water allowing to distinguish tap water, reused wastewater and desalination of seawater. To our best knowledge, it is the first time that these elements are included altogether into a dynamic CGE model. Our work then showcases how a CGE model can inform policy-makers regarding links between water security and economic growth. We show that water scarcity will have an impact on the South African economy. With an increase of water scarcity by $17 \%$, the CGE model predicts a decrease of South African GDP by $-0.34 \%$ in 2030 . At the same time horizon, the unemployment rate is expected to be $0.1 \%$ higher which represents a loss of 18,000 jobs compared to the baseline year (2013). The impact of water scarcity varies from one sector to another, the most negatively impacted being those related to water. The $17 \%$ increase in water scarcity is also expected to have a negative impact on household welfare in South Africa: by 2030 , household consumption is expected to decrease by $-0.26 \%$ due to water scarcity. Some policies can mitigate the negative impacts of water scarcity. The most promising one is to promote water saving.

This remainder of this article is organized as follows. The following section sets the scene by providing information on water security in South Africa and by summarizing the literature having used CGE models to assess macroeconomic 
impacts of water insecurity on economic growth and population welfare. The following section presents SAWAT, the South African water-CGE model we have developed. Then we provide a macroeconomic assessment of water policies in South Africa. We conclude by discussing policy implications of our work.

\section{Water Security And Economic Growth In South Africa Background information on water security in South Africa}

Water security is currently one of South Africa's most prominent issues. According to the National Water and Sanitation Master Plan ${ }^{[1]}$, South Africa is facing a water crisis caused by insufficient maintenance and investment in water infrastructure, recurrent droughts driven by climatic variation, inequities in access to water and sanitation, deteriorating water quality, and a lack of skilled water engineers.

In April 2017, 14.1 million people still used sanitation facilities below the Reconstruction and Development Programme standard. Only 10.3 million households (64\%) have access to a reliable water supply. Approximately $56 \%$ of South Africa's more than 1,150 municipal wastewater treatment works and approximately $44 \%$ of its 962 water treatment works are in poor or critical condition and in need of urgent rehabilitation and skilled operators. Some $11 \%$ of this infrastructure is completely dysfunctional. Between 1999 and 2011, the extent of South Africa's main rivers classified as being in poor ecological condition increased by $500 \%$, with some rivers pushed beyond the point of recovery. South Africa has lost over $50 \%$ of its wetlands, and a third of the remaining 3.2 million hectares are already in a poor condition.

This water crisis is already having significant negative effects on the economy ${ }^{[2]}$, including revenue generation and the cost of treating water; economic productivity and growth; the wellbeing of the population; tourism; and access to water for productive uses (water-use authorizations). If water demand in South Africa continues to grow at current levels, the deficit between water supply and demand could rise to between 2.7 and 3.8 billion $\mathrm{m}^{3}$ per year by 2030 , a gap which represents about $17 \%$ of available surface water and groundwater resources. ${ }^{[3]}$

\section{Policy options to mitigate the impact of the water crisis in South Africa}

The National Water and Sanitation Master Plan has identified a number of critical priority actions that can be implemented to address the current crisis in the water sector and to achieve the sector's constitutional and legal mandate.

${ }^{[4]}$ The National Water and Sanitation Master Plan prioritizes the actions that will deliver the greatest impact with limited resources, with a focus on reducing water demand, increasing supply, ensuring universal, reliable and safe supply and sanitation, protecting infrastructure through effective asset management, improving raw water quality, and ensuring equity in access to water. Some priorities mentioned in the conclusion of Volume 2 of the National Water and Sanitation Master Plan should be stressed. Currently the sector is not financially sustainable and increases in excess of inflationary targets will be required to address the historical undervaluation of water and sanitation services. Addressing high levels of water loss is a critical element in reducing water demand. Non-revenue water levels in municipalities are estimated at an average of $41 \%$. As a result, municipalities are losing around R9.9 billion of potential revenue per year. The reduction of water losses and the introduction of water conservation and demand management measures in municipalities must be enforced to achieve the targets in the National Development Plan. Lastly, a national program has also been proposed to support the adoption of alternative water sources such as desalination and water reuse. 


\section{Using CGE models for assessing macroeconomic impact of water (in)security}

CGE models can assess water management issues because they compare the effects of various water policy scenarios as part of the whole economy. In their review of the literature on the introduction of water into CGE models, Ponce et al. (2012) stress the general lack of details on non-agricultural sectors and on water-intensive industrial sectors. They also find that most reviewed studies essentially examine a loss of water productivity instead of an explicit loss of water availability. In general, CGE models applied to water analyze the impacts of policies on water pricing (demand management), trade (virtual water), supply increase (new investments) and the consequences of water scarcity. These topics are studied at international, national or local level.

At the international level, CGE models focus on the concept of virtual water, which is the water used to produce commodities (Allan, 1992, 1993). To minimize water use in water-scarce countries, one solution is to increase imports of products that require a lot of water for their production. As the water requirement for food production is large, virtual water is considered as an additional source of water for water-scarce countries. Allan and Olmsted (2003), Berrittela et al. (2007) emphasize the role of virtual water in providing food security in water-scarce regions. Others fear that regions become dependent on global trade and vulnerable to market fluctuations. In an another paper, Berritella et al. (2008) develop a multi-region, multi-sector computable general equilibrium model (GTAP) to assess a series of water tax policies. They find that water taxes reduce water use and lead to shifts in production, consumption and international trade patterns. Countries that do not levy water taxes are nonetheless affected by other countries' taxes. Reductions in water use (welfare losses) are less (more) than linear with the price of water.

However, most countries have no explicit strategy for virtual water trade (Yang and Zehnder, 2002). Few authors study the changes in virtual water trade over time. In particular, Yang et al. (2003) use population predictions to calculate the annual water deficit for water-scarce countries by 2030. Basing their calculations on cereal imports, they found an exponential increase in water scarcity. More recently, Liu et al. (2016) use a CGE model operating at global scale to demonstrate that it can be extremely demanding due to the absence of standardized data, the sheer dimensions caused by intersecting river basins with countries, and difficulties to model demand for and supply of water.

Some water-CGE models have been used in developed countries. Berck, Robinson and Goldman (1991) have evaluated water allocation in the San Joaquim area in California. Their model is developed in order to analyze the impact of a water stock variation (supply shock) on the economy. Their results indicate that a negative water shock induces a change in the production structure, and a fall in agricultural incomes and GDP. Similarly to the study of Goldin and Roland-Holst (1995), water is not produced and is not consumed by households so there is no competition with farmers. Seung et al. (1998) consider transfers of the water resource from agricultural use to recreational use for the Walker River Basin in California. Seung et al. (2000) combine a dynamic CGE model with a demand model for recreational use of water to analyze the temporal effects of water reallocations in the county of Churchill (Nevada). Studying the Arkansas River Basin, Goodman (2000) shows that temporary transfers of water resources are a less expensive option than building new dams or increasing existing storage equipment (water facilities) for this river. Along the same lines, Gomez et al., (2004) analyze the welfare gains of improved allocation of water rights in the Balearic Islands. These studies propose an explicit representation of water as a factor of production compared to other studies which use agricultural productivity (Horridge et al., 2005) or land productivity (Seung et al., 2000) as a proxy for water. Ettouney et al., (2002) as well as Zhou and Tol (2005) simulate the impacts of the desalination of brackish water or seawater. Qureshi et al. (2012) use a multi-regional water-CGE model for Australia. They show that the increase in water demand will significantly increase the opportunity cost of water use in major urban centers. Recently, the implications of uncertainty in the technology of irrigation water management has been introduced in a CGE model in Spain, Sánchez Chóliz and Sarasa (2019). 
A large number of applications of water-CGE models have been conducted in developing countries. Firstly, Goldin and Roland-Holst (1995) examine the relations between water management policies and foreign trade in Morocco using a CGE model composed of four sectors, two of which are agricultural and localized in arid and non-arid areas. Diao and Roe $(2000,2003)$ develop a CGE model to analyze the consequences of a protectionist agricultural policy in Morroco. They show how the liberalization of agricultural markets creates the necessary conditions for the implementation of efficient water pricing (particulary through the possibility of a market for water in the rural sector). Dixon (1990), Horridge et al. (1993), Decaluwé et al. $(1998,1999)$, and Thabet (2003) analyze the impacts in terms of the efficiency of various water pricing policies in static CGE models, but the analysis is restricted to the agricultural sector. In Senegal, Briand (2006, 2008) simulates two water-pricing policies (marginal cost and average cost) considering all water-user sectors (agricultural, industrial and services) in a context of climate change (a water resources variability). Some water-CGE have been developed in China, see Zhang et al. (2020) for a recent example.

Table 1 Water-CGE models for South Africa

\begin{tabular}{|c|c|c|c|c|c|}
\hline & Coverage & $\begin{array}{l}\text { Economic } \\
\text { sectors }\end{array}$ & $\begin{array}{l}\text { Production } \\
\text { factors }\end{array}$ & $\begin{array}{l}\text { Household } \\
\text { types }\end{array}$ & $\begin{array}{l}\text { Year } \\
\text { of the } \\
\text { SAM }\end{array}$ \\
\hline Mukherjee (1996) & $\begin{array}{l}\text { Olifants River } \\
\text { Watershed } \\
\text { (Transvaal) }\end{array}$ & 10 & $\begin{array}{l}15 \text { including a land-water } \\
\text { aggregate }\end{array}$ & 11 & NA \\
\hline $\begin{array}{l}\text { Letsoalo et al. } \\
\text { (2007) }\end{array}$ & South Africa & 65 & NA & 48 & 1998 \\
\hline $\begin{array}{l}\text { Van Heerden et al. } \\
(2008)\end{array}$ & South Africa & 39 & $\begin{array}{l}14 \text { ( } 11 \text { labor types, land, capital, } \\
\text { water) }\end{array}$ & 48 & 1998 \\
\hline \multirow{2}{*}{$\begin{array}{l}\text { Juana, Strzepek } \\
\text { and Kirsten (2011) }\end{array}$} & \multirow[t]{2}{*}{ South Africa } & \multirow[t]{2}{*}{13} & 5 (water, capital and & \multirow[t]{2}{*}{5} & \multirow[t]{2}{*}{1998} \\
\hline & & & 3 labor types) & & \\
\hline $\begin{array}{l}\text { Hassan and } \\
\text { Thurlow (2011) }\end{array}$ & $\begin{array}{l}\text { South Africa (19 } \\
\text { regions) }\end{array}$ & 40 & $\begin{array}{l}6 \text { (3 labor types, agricultural land, } \\
\text { irrigation water, and capital) }\end{array}$ & 10 & 2000 \\
\hline
\end{tabular}

NA: not available

Lastly, water-CGE models have been proposed for South Africa (see Table 1). They vary according to the number of economic sectors represented, the number of production factors and the disaggregation of households into income classes. One common feature of all models presented in Table 1 is that they are all static CGE models. The main focus of these works has been to assess the impact of water charges (Letsoalo et al., 2007; Hassan and Turlow, 2011) and to simulate macroeconomic changes resulting from intra-sectoral water reallocation (Juana, Strzepek and Kirsten,2011; Hassan and Turlow, 2011).

One of the first CGE model for South Africa with an explicit representation of water is presented in Mukherjee (1996). This CGE model is applied to the Olifants River Watershed (Transvaal). Two sets of simulations are considered. First, some shocks on water availability are simulated $(-15 \%,-30 \%,-45 \%,-60 \%$ and $-75 \%)$. Changes in most economy-wide indicators such as GDP are relatively small. However, agricultural output declines strongly, by nearly $10 \%$, when water availability is reduced by $60 \%$. The second set of simulations refers to the implementation of land and water reform (reduction of land availability, positive productivity shock on agriculture, reduction of water availability). Both real and nominal GDP decrease, as does agricultural output. An another CGE model developed by Juana, Strzepek and Kirsten (2011) analyze the impact of water reallocation on output growth and value added. This scenario consists in transferring $30 \%, 20 \%, 10 \%$ and $5 \%$ of water from agriculture to non-agricultural sectors. The simulation results show that market allocation of water among the production sectors generally leads to a growth in sectoral output, although the output of agriculture and 
related sectors declines. A disaggregated model (65 economic sectors and 48 types of households) has been provided by Letsoalo et al. (2007) in order to test the triple dividend hypothesis which states that the environmental taxes can simultaneously stimulate economic growth, poverty reduction and environmental protection. In the social accounting matrix (SAM), the water-related informations for each sector are: 1/ water volumes, namely water extracted from underground or rivers, or water received from the formal water sector; and 2/ taxable water used, and extra water charges. The authors conclude that triple dividend is possible for water policy in South Africa. Finally, Hassan and Turlow (2011) use a detailed multi-regional CGE model which includes rainfed and irrigated crop production. A new and unique feature of the SAM is its disaggregation of production and consumption activities by 19 water management areas. Hassan and Thurlow (2011) analyze different policy in South Africa's water use and allocation system. They show several tradeoffs between general economic gains and higher water prices which raise serious questions about subsidizing water supply to irrigated agriculture. The authors estimate that the benefits of water reallocation within the agricultural sector and across water board regions within the country would amount to a recurring economic gain equal to $4.5 \%$ of agricultural GDP.

[1] National Water and Sanitation Master Plan, volume 1.

${ }^{[2]}$ National Water and Sanitation Master Plan, Water and the Economy.

[3] National Water and Sanitation Master Plan, volume 1.

[4] National Water and Sanitation Master Plan, volume 2.

\section{Building A Water-cge Model To Inform Decision-making In South Africa SAWAT: A water-CGE model for South Africa}

The water-CGE model SAWAT represents an economy made of nine activities (production sectors): Agriculture, hunting, forestry, fishing (AGR); Mining, food, textiles (MIN); Oil, mineral products, transport equipment, electricity, gas (OIL); Construction (CNS); Services (TRA); Public services (GVT), Standard production of tap water (TAPWS); Reuse of wastewater (TAPWR); Desalination of seawater (TAPWD). The last three sectors (standard production of tap water, reuse of wastewater and desalination of seawater) contribute to tap water production with differentiated costs because they rely on different technologies which do not use the same inputs in the transformation process. Finally, there are eight commodities with prices defined on markets. They correspond to the typical output of each sector, except for the public sector where the service is considered to be supplied but not purchasable.

The CGE model belongs to the family of sequential dynamic CGE models which enables the production of long-term simulations. The model has two other important characteristics. First, it accounts for unemployment which is endogenously determined. Second, three types of households are represented according to their income level: low income; middle income; high income. Lastly, water resources are considered as production factors, and not as intermediate or final goods. ${ }^{[1]}$ In addition, the intermediate or final good consumed by the agents is drinking water and not directly water resources. Indeed, water resources have to be transformed into tap water with specific technologies and this corresponds to the definition of an intermediate good and not that of a final good.

The water-CGE model SAWAT is inspired by the neoclassical model EXTER developed by Decaluwé, Martens and Savard (2001) but differ in many aspects. The model distinguishes six production factors (labor, capital, surface water, groundwater, wastewater, seawater). Substitution elasticities between labor, capital and scarce water resources are also important. Indeed, with capital fixed, this factor should be a poor substitute for water, while labor should be a good substitute (Letsoala et al., 2007). We choose to calibrate Cobb Douglas parameters (elasticities) from SAM data rather than choosing free values. To take into account household "poverty", the model integrates a linear expenditure system (LES) in which each commodity has a minimum consumption (to respond to subsistence needs). The model takes into 
account all the transfers between households, firms, government and the rest of the world. An efficiency wage and an unemployment function are introduced. Lastly, the water-CGE model is dynamic (recursive sequential).

The CGE model is composed of seven blocks of equations: production in perfect competition, income and savings, taxes, demand, prices, foreign trade, and equilibrium conditions (see Appendix A for a detailed description). The CGE model distinguishes quantity effects (changes in volume) from price effects (changes in value). The model describes an economy using six factors of production: labor, capital, surface water, groundwater, wastewater, seawater. Two factors are standard: labor and capital. The main originality of the model is to consider that some activities (sectors) can use four types of water resources: surface water, groundwater, wastewater or seawater. Surface water and groundwater can be considered as "standard" water resources which have to be transformed into tap water. However, wastewater and seawater constitute additional water resources requiring a particular treatment before use (specific technology with differentiated production costs).

\section{Social Accounting Matrix (SAM) to calibrate SAWAT}

Initially, a Social Accounting Matrix (SAM) for the whole of South Africa (SA) was created. In addition, many adjustments were necessary to adapt it to the specific issue of water scarcity and to the available data. The SA SAM represents revenues in rows and expenses in columns. The sum of revenues and expenses constitute a balance among row totals and column totals. United Nations data and in particular the 2016 report, which tracks all flows of the national economy for 2012, were used to build the South Africa SAM.

A number of sectors have been aggregated to obtain a level of detail that corresponds better to the needs of the study. We initially considered the 62 economic sub-sectors of the original matrix and clustered them into nine sectors. Table 2 represents the GDP share (in the SAM) of each sector.

Table 2 GDP shares per sector (in the SAM of SAWAT, 2012)

\begin{tabular}{|lll|}
\hline & Sector & GDP share \\
\hline AGR & Agriculture, hunting, forestry, fishing & $2.2 \%$ \\
\hline MIN & Mining, food, textiles & $6.1 \%$ \\
\hline CHM & Oil, mineral products, transport equipment, electricity, gas & $14.7 \%$ \\
\hline CNS & Construction & $1.9 \%$ \\
\hline TRA & Services & $46.2 \%$ \\
\hline GVT & Public services & $27.1 \%$ \\
\hline TAPWS & Standard production of tap water & $1.4 \%$ \\
\hline TAPWR & Reuse of wastewater & $0.3 \%$ \\
\hline TAPWD & Desalination of seawater & $0.1 \%$ \\
\hline
\end{tabular}

To better interpret the results of the model, three groups of households have been considered: low, middle and high income. The study therefore proceeded to aggregate the results based on the 14 categories of households classified by income in the original matrix. Recent studies on poverty in South Africa were used to adopt the following distribution for household categories: $60 \%$ of the population for low income, $30 \%$ for middle income and $10 \%$ for high income. 
The 2016 report on electricity, gas and water from the National Statistics Office (Stats SA) for 2018 distinguishes electricity, gas and water expenditures and revenues. This first isolation of the "water account" has been followed by more precise reprocessing. To transform this SAM into a water SAM, important work has been done on the water account, enabling us to allocate the different amounts of water used by sector using the data from the 2018 National Water Accounts Report. We also drew on detailed production cost data provided by Barry Martin, Director of Water \& Sanitation at Nelson Mandela Bay Metropolitan Municipality, adapting them at the national level to distinguish differences in production cost among various water-supply technologies.

Eventually, the different types of water (surface water, groundwater, wastewater, seawater) in the model were classified and quantified using the 2017 Department of Water and Sanitation (DWS) Master Plan.

The calibration step consists in reproducing the baseline equilibrium of the SAM (year 2012) which describes the initial situation (TO). The CGE model is run without any scenario of change: the model (system of equations with endogenous variables that describes perfectly all the relationships between the agents/sectors) computes the value for each variable for the initial situation. If the value computed equals the SAM value, the model is calibrated and is therefore able to run scenarios of change. Running these scenarios is performed by changing (shocking) the value of selected "exogenous" variables. In this way, the study reveals how the shock affects the SA economy and how the SA economy adapts. 2012 (T0) represents the year of calibration, or the initial situation, and the simulations are performed until 2030. Short-term effects are in 2013 (T1) and long-term effects are in 2030 (T18).

\section{Scenarios simulated with SAWAT}

Developing scenarios has been a highly participative process, involving national and local stakeholders in the discussion. A reference group has been established at the national level to provide feedbacks on the study. This national reference group was made up of representatives from various public institutions in charge of water management in South Africa (in particular from the DWS, the Water Research Commission, and the South African Local Government Association). Three meetings were organized with the national reference group, in April, August and November 2019.

We have considered two scenarios related to water. Scenario so "No water scarcity" is a hypothetical situation in which water scarcity remains at its current level. This is clearly unrealistic, but it provides a benchmark corresponding to a situation without the predicted 17\% water deficit in South Africa. Scenario S1 "Water scarcity" represents a situation in which, compared to 2012, there is a $17 \%$ additional water deficit by 2030 . As indicated by the DWS Master Plan, this scenario refers to the projected $17 \%$ shortage in water supply with "business as usual" that is without implementing any particular policy.

The aim of the CGE models is to compare different water policies in terms of mitigating the economic impacts of water scarcity. Therefore, four water-policy scenarios to mitigate water scarcity have been tested. Scenario S2 "Non-revenue water" corresponds to a reduction of non-revenue water from $44 \%$ to $30 \%$. Non-revenue water induces a number of problems described in 'The Tragedy of the Commons' (Hardin, 1968). The risk is the overexploitation of water resources. Non-revenue water is a crucial issue in South Africa. According to the National Water and Sanitation Master Plan (Volume 1), South African municipalities are losing about 1,660 million $\mathrm{m}^{3}$ per year through non-revenue water. At a unit cost of $\mathrm{R} 6 / \mathrm{m}^{3}$, this amounts to R9.9 billion each year. The implementation of scenario S2 in the CGE model corresponds to a decrease in the quantity of non-revenue water from $44 \%$ to $30 \%$ by 2030 , and so an equivalent increase in the quantity of water that is priced. Scenario S3 "Water pricing" corresponds to a tap water price increase for all consumers by $10 \%$ relatively to the initial situation (SAM). This scenario uses the water price increase as a way to signal water scarcity. Scenario S4 "Water saving" is modelled as introducing more efficient water use for all economic sectors. The decrease in the quantity of available water resources linked to climate change (scarcity) is partially compensated with this water 
policy, through better management of leaks (for example), allowing an increase in the quantity of water resources that sectors can use. The implementation of scenario S4 in the CGE model consists of a $10 \%$ increase of the scale coefficient in the Cobb-Douglas production function for the agricultural sectors and the three tap water sectors (at each period relative to T0). In particular, this scale parameter captures productivity gains (a better use of water resources): producing more output with the same quantity of water or producing the same output quantity with less water resources. This implies saving water resources in the productive process. Lastly scenario S5 "Water reuse and desalination" corresponds to an increase in water reuse and in desalination of seawater. In the CGE model, for each period relative to T0, the quantity of wastewater and seawater is increased (+50\%) so that the supply of these water-related factors of production increases. Endogenously, the model indicates the sectorial demands for these additional factors taking into account the needs and the implicit new prices of these resources (relative scarcity rents of each water resource). In clear, the implicit prices of wastewater and seawater decrease relatively to the implicit prices of surface water and groundwater. Reused water and desalinated water become more attractive as water resources for sectors.

${ }^{[1]}$ Similar approaches are used in Berck et al. (1991); Robinson and Gehlar (1995); Goodman (2000); Gomez et al. (2004); Thabet (2003); and Briand $(2006,2008)$.

\section{Simulating Scenarios With Sawat}

CGE models can produce a large variety of outcomes. The focus here is on the following five variables of interest. First, we consider the gross domestic product (GDP) defined as the market value of all final goods and services produced in a specific time period. Second, we measure total investment which is the sum of all savings of all economic agents. In SAWAT total investment corresponds to household savings, firms' savings, government savings and foreign savings. Third, we focus on unemployment rate defined as the share of the labor force that is out of work, expressed as a percentage. Fourth, we compute savings for each economic agent as the difference between income \& consumption, direct taxes paid, and transfers paid to other agents. Fifth, we consider household welfare as a measure of household wellbeing. Different indicators exist to perform welfare analysis. and household consumption has long been favored by economists as a proxy for living standards. Here, consumption in volume for all commodities and for all types of households is used as a proxy of welfare.

As indicated previously, the CGE model SAWAT is dynamic. Scenario impacts can be assessed in the short-term and in the long-term. We define short-term impacts as impacts occurring one year after implementing a particular policy or a particular shock into the model. Short-term impacts are those observed in 2013, one year after the policy shock occurrence (in 2012). We define long-term impacts as impacts that will be visible in 2030. The CGE model allows the analysis of long-term impacts due to its dynamic sequential specification: simulations are realized year after year.

\section{What is the cost of water scarcity for South Africa?}

The Water-CGE model simulates the scenario with a water-scarcity increase of 17\% (S1) and the scenarios where the water-scarcity increase is mitigated by different water policies (S2, S3, S4, S5). Their implementation leads to differentiated effects in the short and long-term. The results of these simulations are presented in Tables $3 \mathrm{a}$ and $3 \mathrm{~b}$ for short-term and long-term effects, respectively. 
Table 3a

Macroeconomic impacts of scenarios in the short-term for South Africa

\begin{tabular}{|c|c|c|c|c|c|c|c|c|c|c|c|}
\hline & \multirow{3}{*}{$\begin{array}{l}\text { So } \\
\text { No } \\
\text { Scarcity } \\
2013\end{array}$} & \multirow{2}{*}{\multicolumn{2}{|c|}{$\begin{array}{l}\text { S1 } \\
\text { Scarcity } \\
\text { (17\% } \\
\text { increase) }\end{array}$}} & \multirow{2}{*}{\multicolumn{2}{|c|}{$\begin{array}{l}\text { S2 } \\
\text { Decrease non- } \\
\text { revenue water } \\
30 \%\end{array}$}} & \multirow{2}{*}{\multicolumn{2}{|c|}{$\begin{array}{l}\text { S3 } \\
\text { Increase tap } \\
\text { water prices } \\
10 \%\end{array}$}} & \multirow{2}{*}{\multicolumn{2}{|c|}{$\begin{array}{l}\text { S4 } \\
\text { Increase } \\
\text { water saving } \\
10 \%\end{array}$}} & \multirow{2}{*}{\multicolumn{2}{|c|}{$\begin{array}{l}\text { S5 } \\
\text { Increase } \\
\text { wastewater and } \\
\text { seawater supply } \\
50 \%\end{array}$}} \\
\hline & & & & & & & & & & & \\
\hline & & 2013 & $\begin{array}{l}\text { S1- } \\
\text { s0 }\end{array}$ & 2013 & S2-S1 & 2013 & $\begin{array}{l}\text { S3- } \\
\text { s1 }\end{array}$ & 2013 & $\begin{array}{l}\text { S4- } \\
\text { S1 }\end{array}$ & 2013 & S5-S1 \\
\hline GDP & -0.04 & -0.27 & -0.23 & 0.17 & 0.44 & -0.26 & 0.01 & 0.35 & 0.62 & -0.07 & 0.2 \\
\hline $\begin{array}{l}\text { Total } \\
\text { investment }\end{array}$ & 0.04 & 0.14 & 0.1 & 0.05 & -0.09 & 0.12 & -0.02 & 0.18 & 0.04 & 0.24 & 0.1 \\
\hline $\begin{array}{l}\text { Unemployment } \\
\text { rate }\end{array}$ & -0.04 & 0.00 & -0.04 & -0.09 & -0.09 & 0.01 & 0.01 & -0.39 & -0.39 & -0.14 & -0.14 \\
\hline
\end{tabular}

For each variable and each scenario (S1 to S5), the first column gives the \% change compared to 2012. The second column provides the difference between the considered scenario and SO (no water scarcity).

Table 3b

Macroeconomic impacts of scenarios in the long-term for South Africa

\begin{tabular}{|c|c|c|c|c|c|c|c|c|c|c|c|}
\hline & \multirow{3}{*}{$\begin{array}{l}\text { So } \\
\text { No } \\
\text { Scarcity } \\
2030\end{array}$} & \multirow{2}{*}{\multicolumn{2}{|c|}{$\begin{array}{l}\text { S1 } \\
\text { Scarcity } \\
\text { (17\% } \\
\text { increase) }\end{array}$}} & \multirow{2}{*}{\multicolumn{2}{|c|}{$\begin{array}{l}\text { S2 } \\
\text { Decrease } \\
\text { non- } \\
\text { revenue } \\
\text { water 30\% }\end{array}$}} & \multirow{2}{*}{\multicolumn{2}{|c|}{$\begin{array}{l}\text { S3 } \\
\text { Increase tap } \\
\text { water prices } \\
10 \%\end{array}$}} & \multirow{2}{*}{\multicolumn{2}{|c|}{$\begin{array}{l}\text { S4 } \\
\text { Increase } \\
\text { water saving } \\
10 \%\end{array}$}} & \multirow{2}{*}{\multicolumn{2}{|c|}{$\begin{array}{l}\text { S5 } \\
\text { Increase } \\
\text { wastewater and } \\
\text { seawater supply } \\
\mathbf{5 0 \%}\end{array}$}} \\
\hline & & & & & & & & & & & \\
\hline & & 2030 & $\begin{array}{l}\text { S1- } \\
\text { s0 }\end{array}$ & 2030 & $\begin{array}{l}\text { S2- } \\
\text { S1 }\end{array}$ & 2030 & $\begin{array}{l}\text { S3- } \\
\text { S1 }\end{array}$ & 2030 & $\begin{array}{l}\text { S4- } \\
\text { S1 }\end{array}$ & 2030 & S5-S1 \\
\hline $\begin{array}{l}\text { GDP (\% } \\
\text { change) }\end{array}$ & 20.02 & 19.68 & -0.34 & 20.37 & 0.69 & 19.69 & 0.01 & 20.60 & 0.92 & 20.8 & 1.12 \\
\hline $\begin{array}{l}\text { Total } \\
\text { investment } \\
\text { (\% change) }\end{array}$ & 17.70 & 17.52 & -0.18 & 17.94 & 0.42 & 17.51 & -0.01 & 18.19 & 0.67 & 17.81 & 0.29 \\
\hline $\begin{array}{l}\text { Unemployment } \\
\text { rate (level) }\end{array}$ & 29.4 & 29.5 & 0.1 & 29.4 & -0.1 & 29.5 & 0.0 & 29.3 & -0.2 & 29.9 & 0.40 \\
\hline \multicolumn{12}{|c|}{ GDP: \% change compared to 2012} \\
\hline \multicolumn{12}{|c|}{ Total investment: \% change compared to 2012} \\
\hline
\end{tabular}

In the short term, compared to a situation without water scarcity (SO), the SAWAT predicts a decrease in GDP due to water scarcity (S1) equal to $-0.23 \%$ for the year following the water-scarcity shock (2013), see Table 3a. The South African economy is trying to adapt to this constraint on water resource availability by increasing total investment and so, production capacities $(+0.10 \%)$. The economic sectors are able to modify their mix of production factors, increasing the quantities of capital and labor necessary to produce in a context of increased water scarcity. This corresponds to a substitution effect between production factors. Producers adjust their production processes by modifying the relative quantities of production factors. This explains why, in 2013 , total investment increases $(0.1 \%)$ and the unemployment rate 
decreases (-0.04\%). In the long-term (2030), an increase of water scarcity by $17 \%$ (S1) induces a decrease in GDP by $-0.34 \%$, see Table $3 b$. The South African economy is not able to totally mitigate the impact of water scarcity: total investment decreases $(-0.18 \%$ ) and the unemployment rate increases (to $29.5 \%$ compared to $29.4 \%$ in a situation without increase in water scarcity). The South African economy is constrained by water scarcity, which is not compensated by additional investments or by reallocation of other production factors. Therefore, additional water policies are required (S2 to S5).

\section{Can the South African economy mitigate the impacts of water scarcity?}

We first consider S2 which corresponds to decreasing non-revenue water from $44-30 \%$. In this scenario a greater quantity of water resources is "internalized" by the market by decreasing the volume of non-revenue water. In the short-term, this policy results in a GDP increase $(0.44 \%)$ and a decrease of the unemployment rate $(-0.09 \%)$. As total savings slightly decreases (since firms pay more to access water resources their expenditures are higher), total investment also slightly decreases. In the long-term (2030), GDP is expected to increase by $0.69 \%$ compared to S1, and the unemployment rate to decrease by $-0.1 \%$. The impacts of this policy are stronger in the long-term (2030) compared to the short-term (2013). Next, we focus on S4, the policy consisting in increasing water saving by $10 \%$. This policy is particularly beneficial for the GDP and for unemployment in 2013 (short-term). The (S4-S1) comparison shows that the gain in terms of GDP is $0.62 \%$. The unemployment rate decreases significantly $(-0.39 \%)$. The South African economy invests for the future since total investment increases by $+0.04 \%$. Payment for access to water resources allows agents to benefit from an additional income. In the long-term as well, increasing water saving is beneficial in terms of GDP (+ $0.92 \%)$ and unemployment $(-0.2 \%)$. Moreover, the South African economy can invest more for the future $(+0.67 \%)$. Aggregate income increases more than aggregate expenditures, so national savings increase. The policy scenario S5 consists in increasing wastewater and seawater (+50\%). This policy is beneficial for the economy in the short-term. The (S5-S1) comparison shows that the gain in terms of GDP is $0.2 \%$. The unemployment rate decreases $(-0.14 \%)$. This policy is particularly beneficial in terms of investment for the future: total investment increases by $+0.1 \%$. In the long-term, this policy is the most beneficial for the economy in terms of growth. The (S5-S1) comparison shows that the gain in terms of GDP is $1.12 \%$. But the unemployment rate increases $(0.4 \%)$ because growth is due to the use of new water resources. Sectors produce more with less labor, which is substituted by water resources. Total investment increases $(+0.29 \%)$ because aggregate savings increase. Additionally, a "regulation by prices" policy is tested in S3, in which tap water prices are increased for all consumers by $10 \%$. In the long-term, as in the short-term, this policy has only limited effects on the economy of South Africa. If GDP increases marginally (0.01\%), the unemployment rate does not change, and total investment also decreases marginally $(-0.01 \%)$. The increase of the tap water production cost (each period) weighs on sectors and households. These results differ from Letsoalo et al. (2007) who report that there is a triple dividend associated to increasing water consumption charges in South Africa. In their CGE analysis, they indeed find that water charges may simultaneously limit water scarcity, improve economic growth (reduce unemployment), and reduce poverty. Discrepancies in water demand price elasticities and in the way production technologies are represented in the two CGE models may explain these results.

To summarize, in the short-term, with S2, S4 and S5 it appears possible to cancel out water-scarcity impacts and to generate some additional positive macroeconomic effects on the South African economy. The strongest impacts are observed by increasing water saving (S4).

\section{What are the sectoral impacts of water scarcity for South Africa?}


Table 4

a Sectoral GDP impacts of scenarios in the short-term for South Africa

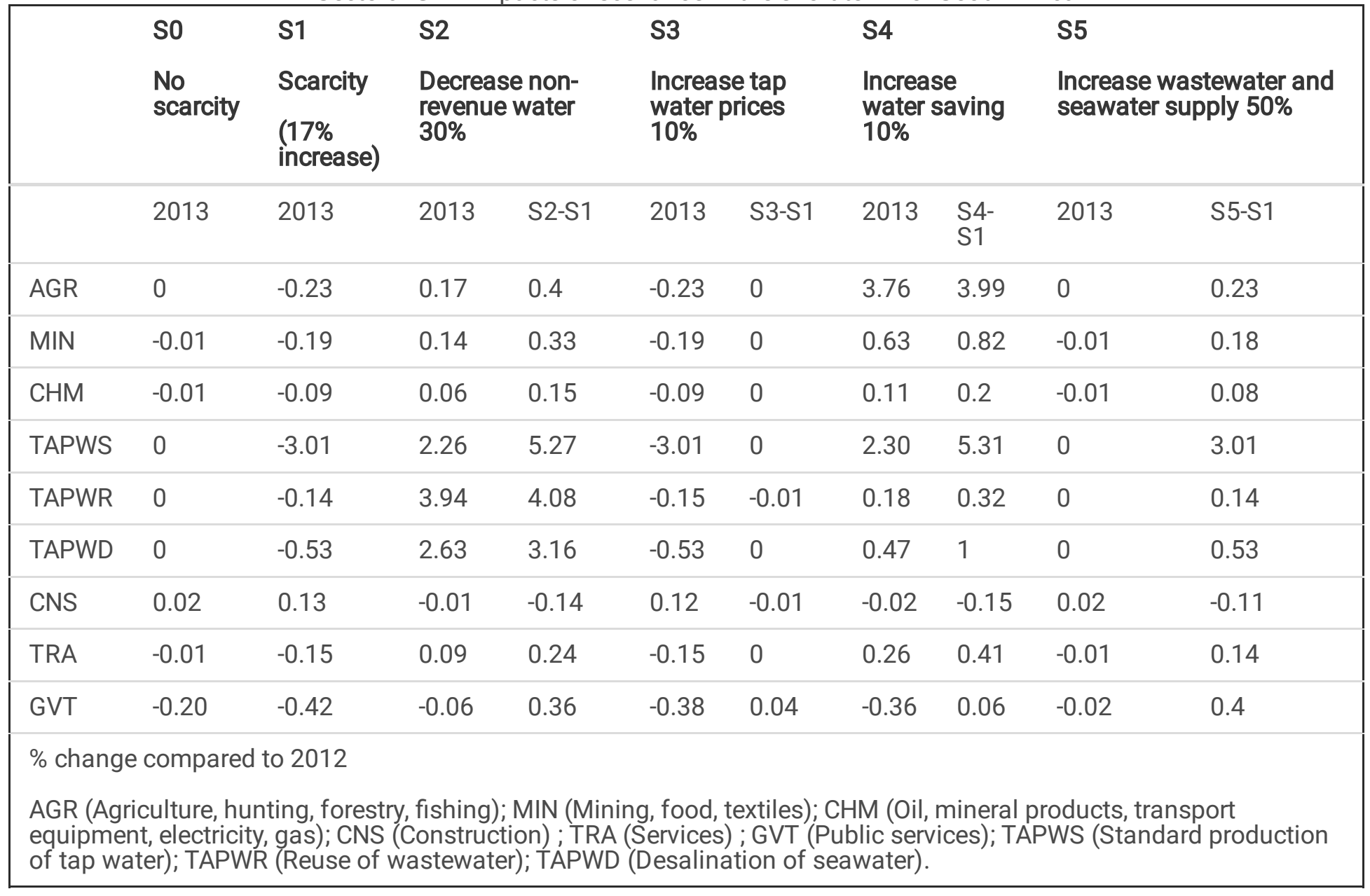


Table 4

b Sectoral GDP impacts of scenarios in the long-term for South Africa

\begin{tabular}{|c|c|c|c|c|c|c|c|c|c|c|c|}
\hline & so & S1 & & $S 2$ & & S3 & & S4 & & S5 & \\
\hline & $\begin{array}{l}\text { No } \\
\text { scarcity }\end{array}$ & $\begin{array}{l}\text { Scarcit } \\
(17 \% \\
\text { increas }\end{array}$ & & $\begin{array}{l}\text { Decrea } \\
\text { revenu } \\
30 \%\end{array}$ & $\begin{array}{l}\text { non- } \\
\text { water }\end{array}$ & $\begin{array}{l}\text { Increas } \\
\text { water } \\
10 \%\end{array}$ & tap & $\begin{array}{l}\text { Increa } \\
\text { water } \\
10 \%\end{array}$ & ving & $\begin{array}{l}\text { Increa } \\
\text { and se } \\
50 \%\end{array}$ & $\begin{array}{l}\text { stewater } \\
\text { er supply }\end{array}$ \\
\hline & 2030 & 2030 & $\begin{array}{l}\text { S1- } \\
\text { s0 }\end{array}$ & 2030 & S2-S1 & 2030 & S3-S1 & 2030 & $\begin{array}{l}\text { S4- } \\
\text { S1 }\end{array}$ & 2030 & S5-S1 \\
\hline AGR & 20.76 & 20.42 & -0.34 & 21.09 & 0.67 & 20.42 & 0 & 23.73 & 3.31 & 20.71 & 0.27 \\
\hline MIN & 25.53 & 25.16 & -0.37 & 25.89 & 0.73 & 25.16 & 0 & 26.45 & 1.29 & 25.5 & 0.34 \\
\hline $\mathrm{CHM}$ & 25.64 & 25.37 & -0.27 & 25.93 & 0.56 & 25.37 & 0 & 26.06 & 0.69 & 25.69 & 0.32 \\
\hline TAPWS & 13.14 & 10.66 & -2.48 & 15.11 & 4.45 & 10.64 & -0.02 & 15.16 & 4.5 & 11.06 & 0.4 \\
\hline TAPWR & 13.87 & 13.5 & -0.37 & 17.36 & 3.86 & 13.49 & -0.01 & 14.3 & 0.8 & 23.82 & 10.32 \\
\hline TAPWD & 12.7 & 11.93 & -0.77 & 14.57 & 2.64 & 11.92 & -0.01 & 13.46 & 1.53 & 16.24 & 4.31 \\
\hline CNS & 22.27 & 22.11 & -0.16 & 22.47 & 0.36 & 22.11 & 0 & 22.6 & 0.49 & 22.4 & 0.29 \\
\hline TRA & 21.91 & 21.63 & -0.28 & 22.2 & 0.57 & 21.63 & 0 & 22.43 & 0.8 & 21.92 & 0.29 \\
\hline GVT & 4.28 & 4.18 & -0.1 & 4.35 & 0.17 & 4.19 & 0.01 & 4.11 & -0.07 & 4.27 & 0.09 \\
\hline & $\%$ chang & ompare & to $20^{\circ}$ & & & & & & & & \\
\hline & $\begin{array}{l}\text { AGR (Ag } \\
\text { transpor } \\
\text { (Standar }\end{array}$ & $\begin{array}{l}\text { ulture, h } \\
\text { quipme } \\
\text { product }\end{array}$ & $\begin{array}{l}\text { nting, } \\
\text {, electr } \\
n \text { of ta }\end{array}$ & $\begin{array}{l}\text { restry, fi } \\
\text { ity, gas) } \\
\text { water); }\end{array}$ & $\begin{array}{l}\text { ing); M } \\
\text { ANS (Co } \\
\text { PWR (F }\end{array}$ & $\begin{array}{l}\text { (Mining } \\
\text { truction } \\
\text { se of } n\end{array}$ & $\begin{array}{l}\text { food, tex } \\
\text {; TRA (S } \\
\text { stewate }\end{array}$ & $\begin{array}{l}\text { iles); Cl } \\
\text { rvices) } \\
\text {;TAPW }\end{array}$ & $\begin{array}{l}\text { M (Oil, r } \\
\text { GVT (Pi } \\
\text { (Desal }\end{array}$ & $\begin{array}{l}\text { ineral } p \\
\text { blic serv } \\
\text { iation o }\end{array}$ & $\begin{array}{l}\text { ts, } \\
\text { TAPWS } \\
\text { water). }\end{array}$ \\
\hline
\end{tabular}

In Table 4a and 4b, we investigate the winning and losing sectors according to each scenario in the short-term and in the long-term, respectively. In the short-term, Table 4a shows that water scarcity is particularly disadvantageous for the "standard production of tap water" sector. The loss in terms of GDP is $3.01 \%$. The increase in the price of drinking water can counterbalance the negative effects of the scarcity of resources in each sector. The "construction" sector is a small loser. With the water saving policy (S4), the model predicts strong impacts in terms of sectoral GDP for the agricultural sector $(+3.99 \%)$ and for the standard production of tap water $(+5.31 \%)$. Both sectors benefit from the increase in the marginal efficiency of water resources in their production technology. Increasing water saving (S4) is a pro-food-security and pro-water-security policy in the short-term (2013). Tradable services are also positively impacted. These results explain the decrease in the unemployment rate because all these sectors are hiring more labor. Table $4 \mathrm{~b}$ provides sectoral GDP impacts of scenarios in the long-term. With increasing water scarcity (SA), all sectors lose in terms of GDP. S2 (decreasing non-revenue water) is particularly beneficial for the three production sectors of tap water (sectoral GDP increases by $4.45 \%, 3.86 \%$ and $2.64 \%$ for standard, reuse and desalination sectors, respectively). Increasing the share of water resources is a source of income for the economy and a source of better management (an efficient allocation of water resources between sectors). S3 (increase of water pricing) can counterbalance the negative effects of resources scarcity for all sectors. Short-term and long-term effects are very similar. With the "water saving" policy (S4), the model predicts strong impacts on sectoral GDP for agriculture (+3.31\%), mining $(+1.29 \%)$ and the standard production of tap water $(+4.5 \%)$. Similarly to the short-term analysis, these sectors benefit from an increase of the marginal efficiency of water resources in their production technology.

Both in the short-term and in the long-term, S4 is the most promising scenario in terms of achieving food security and water security. On the contrary, the benefits of S5 (increase in wastewater and seawater) are more limited because 
spillovers generated by the growth of reuse/desalination sectors are not enough to generate gains for the different sectors of the South African economy.

\section{What are the impacts of water scarcity on households for South Africa?}

Tables $5 \mathrm{a}$ and $5 \mathrm{~b}$ present the impacts in terms of welfare for the population. As a proxy of welfare, the consumption in volume for all commodities and for all types of households is used. Changes in total consumption in volume are driven by two mechanisms in the CGE model: change in each household's income (due to changes in wages and prices of other factors) and change in consumer prices (for each commodity). In the following tables, the change in total consumption in volume is computed to assess if the quantity of commodities consumed in the South African economy increases or decreases. This proxy of welfare is also computed for each type of household.

Table 5a Welfare impacts of scenarios in the short-term for South Africa

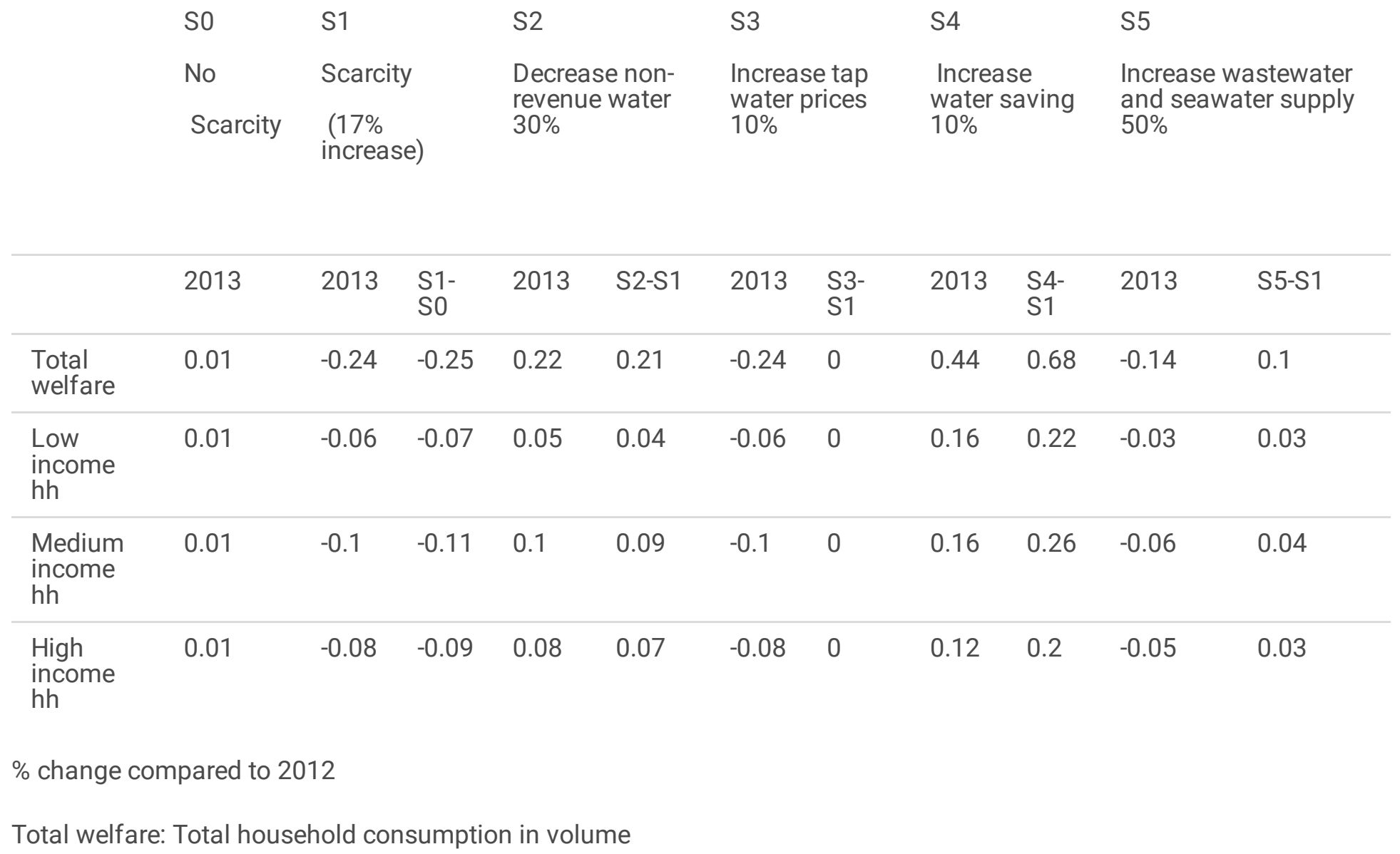

Table 5b Welfare impacts of scenarios in the long-term for South Africa 


\begin{tabular}{|c|c|c|c|c|c|}
\hline so & S1 & S2 & S3 & S4 & S5 \\
\hline & & Decrease non- & Increase tap water & Increase water & Increase \\
\hline Scarcity & $\begin{array}{l}(17 \% \\
\text { increase) }\end{array}$ & $30 \%$ & & & $\begin{array}{l}\text { and } \\
\text { seawater } \\
\text { supply } 50 \%\end{array}$ \\
\hline
\end{tabular}

\begin{tabular}{lcccccccccccc}
\hline & 2030 & 2030 & $\begin{array}{l}\text { S1- } \\
\text { S0 }\end{array}$ & 2030 & $\begin{array}{l}\text { S2- } \\
\text { S1 }\end{array}$ & 2030 & $\begin{array}{l}\text { S3- } \\
\text { S1 }\end{array}$ & 2030 & S4-S1 & 2030 & S5-S1 \\
\hline $\begin{array}{l}\text { Total } \\
\text { welfare }\end{array}$ & 11.14 & 10.88 & -0.26 & 10.88 & 0.00 & 11.37 & 0.49 & 11.54 & 0.66 & 11.1 & 0.22 \\
\hline $\begin{array}{l}\text { Low } \\
\text { income } \\
\text { hh }\end{array}$ & 1.94 & 1.88 & -0.06 & 1.88 & 0.00 & 1.98 & 0.1 & 2.05 & 0.17 & 1.92 & 0.04 \\
\hline $\begin{array}{l}\text { Medium } \\
\text { income } \\
\text { hh }\end{array}$ & 4.42 & 4.31 & -0.11 & 4.31 & 0.00 & 4.52 & 0.21 & 4.57 & 0.26 & 4.39 & 0.08 \\
\hline $\begin{array}{l}\text { High } \\
\text { income } \\
\text { hh }\end{array}$ & 4.78 & 4.69 & -0.09 & 4.68 & -0.01 & 4.87 & 0.18 & 4.92 & 0.23 & 4.76 & 0.07 \\
\end{tabular}

\% change compared to 2012

Total welfare: Total household consumption in volume

In the short-term, with the scarcity scenario (S1), total welfare in the South African economy (aggregation of the welfare of all households) decreases by $-0.25 \%$. The welfare of each type of household decreases: $-0.07 \%$ for low income, $-0.11 \%$ for medium income and $-0.09 \%$ for high income. The increase in water prices counterbalances the negative impacts due to scarcity in terms of welfare (for all categories of households). Once again, the increased water saving policy (S4) is the most beneficial with a welfare increase by $0.68 \%$, and this is true for all classes of income. Medium-income households benefit a little more than other households. In the long-term, the scarcity scenario (S1) decreases total welfare in the longterm (-0.26\%). The welfare for each type of household decreases: $-0.06 \%$ for low income, $-0.11 \%$ for medium income and $-0.09 \%$ for high income. As in the short-term, all households lose (with the same percentage change of welfare). Once again, S4 (increase water saving 10\%) appears to be the most attractive scenario in terms of welfare improvement $(0.66 \%$ increase). As in the short-term, "medium-income" households get the highest share of welfare improvement. S3 and S5 also generate welfare improvements for all types of households, but less than S4. Once again, scenario S4 appears to be dominant both in the long-term and in the short-term, here for the question of welfare.

\section{How do savings react to water scarcity in South Africa?}

Table $6 \mathrm{a}$ and $6 \mathrm{~b}$ focus on the savings structure changes for the South African economy. Saving is the difference between income and expenditure for each "macroeconomic" agent (households, firms, government, rest of the world). For example, firms receive income from their factors of production (capital, in particular) and pay taxes to government and dividends to other agents. The difference between received income and paid taxes and dividends generates savings for the firms. 
Table $6 a$

Savings impacts of scenarios in the short-term for South Africa

\begin{tabular}{|c|c|c|c|c|c|c|c|c|c|c|c|}
\hline & \multirow{3}{*}{$\begin{array}{l}\text { So } \\
\text { No } \\
\text { Scarcity } \\
2013\end{array}$} & \multirow{2}{*}{\multicolumn{2}{|c|}{$\begin{array}{l}\text { S1 } \\
\text { Scarcity } \\
\text { (17\% } \\
\text { increase) }\end{array}$}} & \multirow{2}{*}{\multicolumn{2}{|c|}{$\begin{array}{l}\text { S2 } \\
\text { Decrease non- } \\
\text { revenue water } \\
30 \%\end{array}$}} & \multirow{2}{*}{\multicolumn{2}{|c|}{$\begin{array}{l}\text { S3 } \\
\text { Increase tap } \\
\text { water prices } \\
10 \%\end{array}$}} & \multirow{2}{*}{\multicolumn{2}{|c|}{$\begin{array}{l}\text { S4 } \\
\text { Increase } \\
\text { water saving } \\
10 \%\end{array}$}} & \multirow{2}{*}{\multicolumn{2}{|c|}{$\begin{array}{l}\text { S5 } \\
\text { Increase wastewater } \\
\text { and seawater supply } \\
50 \%\end{array}$}} \\
\hline & & & & & & & & & & & \\
\hline & & 2013 & $\begin{array}{l}\text { S1- } \\
\text { s0 }\end{array}$ & 2013 & S2-S1 & 2013 & $\begin{array}{l}\text { S3- } \\
\text { S1 }\end{array}$ & 2013 & $\begin{array}{l}\text { S4- } \\
\text { S1 }\end{array}$ & 2013 & S5-S1 \\
\hline Firms & 0 & 0.17 & 0.17 & -0.13 & -0.3 & 0.17 & 0 & 0.05 & -0.12 & 0.11 & -0.06 \\
\hline $\begin{array}{l}\text { Low income } \\
\text { hh }\end{array}$ & 0.02 & 0 & -0.02 & 0.04 & 0.04 & 0 & 0 & 0.18 & 0.18 & 0.02 & 0.02 \\
\hline $\begin{array}{l}\text { Medium } \\
\text { income hh }\end{array}$ & 0.02 & 0.01 & -0.01 & 0.05 & 0.04 & 0.01 & 0 & 0.26 & 0.25 & 0.03 & 0.02 \\
\hline $\begin{array}{l}\text { High } \\
\text { income hh }\end{array}$ & 0.02 & 0.02 & 0 & 0.03 & 0.01 & 0.02 & 0 & 0.22 & 0.2 & 0.03 & 0.01 \\
\hline Government & -0.04 & -1.32 & -1.28 & 0.98 & 2.3 & -1.34 & -0.02 & -0.14 & 1.18 & -0.67 & 0.65 \\
\hline Foreign & 0.03 & -0.45 & -0.48 & 0.51 & 0.96 & -0.46 & -0.01 & 0.06 & 0.51 & -0.04 & 0.41 \\
\hline
\end{tabular}

Savings: Difference between income and expenditure

Table 6b

Savings impacts of scenarios in the long-term for South Africa

\begin{tabular}{|c|c|c|c|c|c|c|c|c|c|c|c|}
\hline & \multirow{3}{*}{$\begin{array}{l}\text { So } \\
\text { No } \\
\text { Scarcity } \\
2030\end{array}$} & \multirow{2}{*}{\multicolumn{2}{|c|}{$\begin{array}{l}\text { S1 } \\
\text { Scarcity } \\
\text { (17\% } \\
\text { increase) }\end{array}$}} & \multirow{2}{*}{\multicolumn{2}{|c|}{$\begin{array}{l}\text { S2 } \\
\text { Decrease non- } \\
\text { revenue water } \\
30 \%\end{array}$}} & \multirow{2}{*}{\multicolumn{2}{|c|}{$\begin{array}{l}\text { S3 } \\
\text { Increase tap } \\
\text { water prices } \\
10 \%\end{array}$}} & \multirow{2}{*}{\multicolumn{2}{|c|}{$\begin{array}{l}\text { S4 } \\
\text { Increase water } \\
\text { saving } 10 \%\end{array}$}} & \multirow{2}{*}{\multicolumn{2}{|c|}{$\begin{array}{l}\text { S5 } \\
\text { Increase } \\
\text { wastewater and } \\
\text { seawater supply } \\
50 \%\end{array}$}} \\
\hline & & & & & & & & & & & \\
\hline & & 2030 & $\begin{array}{l}\text { S1- } \\
\text { s0 }\end{array}$ & 2030 & $\begin{array}{l}\text { S2- } \\
\text { S1 }\end{array}$ & 2030 & $\begin{array}{l}\text { S3- } \\
\text { S1 }\end{array}$ & 2030 & $\begin{array}{l}\text { S4- } \\
\text { S1 }\end{array}$ & 2030 & S5-S1 \\
\hline Firms & 25.28 & 25.13 & -0.15 & 25.45 & 0.32 & 25.13 & 0 & 25.78 & 0.65 & 25.37 & 0.24 \\
\hline $\begin{array}{l}\text { Low income } \\
\text { hh }\end{array}$ & 7.84 & 7.75 & -0.09 & 7.94 & 0.19 & 7.74 & -0.01 & 8.1 & 0.35 & 7.86 & 0.11 \\
\hline $\begin{array}{l}\text { Medium } \\
\text { income hh }\end{array}$ & 12.46 & 12.32 & -0.14 & 12.62 & 0.30 & 12.32 & 0 & 12.86 & 0.54 & 12.49 & 0.17 \\
\hline $\begin{array}{l}\text { High } \\
\text { income hh }\end{array}$ & 12.08 & 11.96 & -0.12 & 12.23 & 0.27 & 11.95 & -0.01 & 12.45 & 0.49 & 12.11 & 0.15 \\
\hline Government & -69.51 & -69.58 & -0.07 & -69.56 & 0.02 & -69.61 & -0.03 & -70.84 & -1.26 & -69.89 & -0.31 \\
\hline Foreign & -29.65 & -29.73 & -0.08 & -29.59 & 0.14 & -29.75 & -0.02 & -30.09 & -0.36 & -29.74 & -0.01 \\
\hline
\end{tabular}

Savings: Difference between income and expenditure 
In the short-term, compared to S0, firms' saving increases in the water-scarcity scenario (S1) by $+0.17 \%$ because firms hold a share of factors (in the SAM) and therefore benefit from additional remuneration due to the increase in the implicit price of the water resource (scarcity rent). All other savings decrease. The water price increase (S3) mitigates the negative impacts on household savings and slightly decreases savings for government and the rest of the world. The "water saving" policy (S4) can increase all savings for most agents (except for firms). The public debt (the government has negative savings in the SAM) is reduced since the government earns additional income from direct and indirect taxes. In the long-term, compared to S0, savings decrease in a context of water scarcity (S1). The water price increase (S3) mitigates the negative impacts on household savings and slightly decreases savings for the government and the rest of the world. The "water saving" policy (S4) increases all private savings. However, in the long-term, government savings decrease (-1.26\%) because the government has to finance this policy, and foreign savings decrease $(-0.36 \%)$.

In order to summarize the evolution of the savings generated for each scenario, it is necessary to consider that the South African economy is structured in such a way that firms initially participate in more than $75 \%$ of the formation of total savings in the economy. Thus, by weighting the variations in savings of each economic agent by their initial participation in total savings, it appears that in the short-term, scenario 5 dominates with an increase in total savings of $0.04 \%$ for only $0.02 \%$ in scenario 4 . On the other hand, in the long-term, scenario 4 dominates with an increase in total savings of $0.43 \%$ while this increase in scenario 5 is $0.19 \%$ (even behind scenario 2 which shows an increase in total savings of $0.28 \%$ ).

\section{Main Findings And Conclusions}

We have built a new water-CGE dynamic model calibrated with the most up-to-date data for South Africa. Accordingly, a new SAM centered around water use has been built. Five scenarios of change have been developed and assessed. An impact assessment has been conducted considering both short-term impacts (baseline +1 year) and long-term impacts (2030). The impacts of scenarios have been assessed considering a large variety of microeconomic (i.e. factor production prices), macroeconomic (i.e. GDP, investments, unemployment, exports) and social outcomes (welfare of households) for informing policymakers. The results have been disaggregated by economic sector ( 9 economic sectors) or household type (low, medium, and high income).

We find that water scarcity has a significant impact on the South African economy. With an increase of water scarcity by $17 \%$, the SAWAT CGE model predicts a decrease in South African GDP by $-0.34 \%$ by 2030 . At the same time horizon, the unemployment rate is expected to be $0.1 \%$ higher, which represents a loss of 18,000 jobs compared to the baseline year (2013). The cost of water scarcity varies from one economic sector to another. Household categories (in terms of income) will not be impacted in the same way by the water scarcity increase. Middle-income households are expected to be the most negatively impacted.

Some policies can counterbalance the macroeconomic impacts of water scarcity. The most promising scenario/policy according to the SAWAT CGE model is to increase water saving. In a context of water deficit, a $10 \%$ increase in water saving offers an additional $0.92 \%$ increase in GDP compared to a situation without intervention. This policy results in the highest increase of total investment $(0.67 \%)$ as well as the strongest decrease of the unemployment rate $(-0.2 \%)$. With water reuse and desalinization (scenario 5), the gain in terms of GDP is larger (1.12\%) but the unemployment rate increases $(0.4 \%)$. Scenario 3 ( $10 \%$ increase in tap water prices) only mitigates the negative impacts of water scarcity; it does not generate additional positive impact for the economy.

Compared to the other studies conduced with CGE models, our results demonstrate that a new way is possible in terms of policy: develop the "water saving" seems better to obtain a triple dividend. This way aims to manage the quantity of water input in the production process in order not to have to modify the water prices and to have to increase supply. Manage the effectiveness of the quantity of water in the economy represents the more rational way to mitigate the negative economic effects of the scarcity.

Page 17/21 
The policy implications of our work may be summarized as follows. First, the negative macroeconomic impacts of increased water scarcity on GDP, total investment, unemployment, and household consumption call for implementing specific policies. Since all policies will not have the same macroeconomic impacts (on GDP, total investment, unemployment, and household welfare), they must be carefully designed. The CGE model developed offers a useful way to test those policies and to assess ex ante their impact. Second, the most promising policy appears to be to invest in water saving (scenario S4). In contrast, some policies such as increasing water pricing (scenario S3) are predicted to have only limited effects for mitigating long-term impacts of water scarcity. Third, water policies will have differentiated impacts on economic sectors and household income groups. This calls for a careful design of such policies, and the need to consider redistribution schemes across sectors or household income groups. Differentiation of economic policy scenarios according to household type or economic sector (e.g. water pricing may differ for low-income households or some economic sectors) could be a valid option to consider. Fourth, combining different policy scenarios might be a relevant way to identify an optimal policy mix for mitigating long-term impacts of water scarcity.

Finally, a few extensions of our work may be considered. First, additional policy scenarios may be proposed for simulation by the CGE model. One may think to have differentiated economic policy scenarios according to household type or economic sector (e.g. water pricing may differ for low-income households or some economic sectors). Second, the production function of the sectors could integrate an imperfect substitution between the factors (CES function). Currently, the substitution is perfect because the factors are substitutable according to the respective evolution of their prices. However, technological constraints exist: a CES function can take into account these constraints. Third, one may add different types of labor (e.g. skilled versus non-skilled). Fourth, the granularity of the model could be increases by Introducing more disaggregated economic sectors or by regionalizing it. Lastly, the water-CGE model could be regionalized to account for the wide heterogeneity of South African Provinces in terms of climate conditions, water availability, structure of the economy.

\section{Declarations}

Author Declaration: This work has been realized within the partnership between TSE-P and GIZ Financial support is acknowledged. Authors are grateful to the participants to the national reference group held in Pretoria. Arnaud Reynaud acknowledges funding from ANR under grant ANR-17-EURE-0010 (Investissements d'Avenir program). The authors declare no conflict of interest. Data and GAMS code for running the Water-CGE model are available from authors upon request. All authors have equally contributed to the development of the Water-CGE model, to its implementation on GAMS, to the interpretation of results and to the writing of the article.

\section{References}

1. Allan, J. A. 1992. "Fortunately there are substitutes for water otherwise our hydro-political futures would be impossible", in: Proceedings of the Conference on Priorities for Water Resources Allocation and Management: Natural Resources and Engineering Advisers Conference, Southampton, July 1992, pp. 13-26.

2. Allan, J. A. 1993. "Overall perspectives on countries and regions”, in: Rogers, P., Lydon, P. (Eds.), Water in the Arab World: Perspectives and Prognoses. Cambridge, MA, pp. 65-100.

3. Allan, J. A., \& Olmsted, J. C. (2003). "Politics, economics and (virtual) water: a discursive analysis of water policies in the Middle East and North Africa”. In H. Lofgren (Ed.), Food and Agriculture in the Middle East and North Africa (pp. 53-78). Amsterdam: JAl/Elsevier. (Chap. 5).

4. Arrow, K. J., \& Debreu, G. (1954). "Existence of an Equilibrium for a Competitive Economy". Econometrica, 22(3), 265290. https://doi.org/10.2307/1907353. 
5. Babatunde, K. A., Begum, R. A., \& Said, F. F. (2017). Application of computable general equilibrium (CGE) to climate change mitigation policy: a systematic review. Renewable and Sustainable Energy Reviews, 78, 61-71.

6. Berck, A., Robinson, S., \& Goldman, G. (1991). "The Use of Computable General Equilibrium Models to Assess Water Policies". In A. Dinar \& D. Zilberman (Eds.), The Economic and Management of Water and Drainage in Agriculture. Boston: Kluwer Academic Publishers.

7. Berrittella, M., Hoekstra, A. Y., Rehdanz, K., Roson, R., \& Tol, R. S. J. (2007). The Economic Impact of Restricted Water Supply: A Computable General Equilibrium Analysis. Water Research, 41, 1799-1813.

8. Berrittella, M., Rehdanz, K., Roson, R., \& Tol, R. S. J. (2008). The economic impact of water taxes: a computable general equilibrium analysis with an international dataset. Water Policy, 10(3), 259-271.

9. Bourguignon, F., Branson, W. H., \& De Melo, J. (1989). Macroeconomic Adjustment and Income Distribution: A MacroMicro Simulation Model. OECD. Technical Paper No.1.

10. Bouwer, H. (2000). Integrated Water Management: Emerging Issues and Challenges. Agricultural Water Management, $45,217-228$.

11. Briand, A. 2006. "Marginal Cost Versus Average Cost Pricing with Climatic Shocks in Senegal: A Dynamic Computable General Equilibrium Model Applied to Water", FEEM Working Papers 144, Fondazione Eni Enrico Mattei, Milan (in English).

12. Briand, A. (2008). Les tarifications au coût marginal versus coût moyen face à des chocs climatiques au Sénégal: un modèle dynamique d'équilibre général calculable appliqué à l'eau. Économie et Prévision, $n^{\circ} 185,103-121$. (in French).

13. Burfisher, M. E. (2017). Introduction to Computable General Equilibrium Models. Cambridge University Press.

14. Calzadilla, A., Rehdanz, K., Roson, R., Sartori, M., \& Tol, R. S. J. 2016, "Review of CGE Models of Water Issues”, The WSPC Reference on Natural Resources and Environmental Policy in the Era of Global Change, December 2016, 101123.

15. Decaluwé, B., Patry, A., \& Savard, L. 1999. “When Water is no Longer Heaven Sent: Comparative Pricing Analysis in an AGE Model”, Cahier de recherche $n^{\circ}$ 9908, CREFA, Université Laval, Québec.

16. Decaluwé, B., Patry, A., \& Savard, L. 1998. "Quand l'eau n'est pas un don du ciel: un MEGC appliqué au Maroc”, Revue d'économie du développement 3-4, December, 149-187.

17. Dinar, A. (2000). The political economy of water pricing reforms. World Bank.

18. Dinar, A., Espinola-Arredondo, A., \& Muñoz-Garcia, F. 2017. “The WSPC Reference on Natural Resources and Environmental Policy in the Era of Global Change”, Volume 3: Computable General Equilibrium Models, World Scientific, December 2016. https://doi.org/10.1142/9747.

19. Diao, X., \& Roe, T. (2000). "The Win-Win Effect of Joint and Trade Reform on Interest Groups in Irrigated Agriculture in Morocco". In A. Dinar (Ed.), The Political Economy of Water Pricing Reforms. Oxford University Press.

20. Diao, X., \& Roe, T. 2003. “Can a water market avert the 'double-whammy' of trade reform and lead to a 'win-win' outcome?", Journal of Environmental Economics and Management, $\mathrm{n}^{\circ} 45$.

21. Dixon, P. B. (1990). A General Equilibrium Approach to Public Utility Pricing: Determining Prices for a Water Authority. Journal of Policy Modeling, 12(4), 745-767.

22. Dixon, P. B., \& Jorgenson, D. (Eds.). (2012). Handbook of Computable General Equilibrium Modeling (Vol. 1). North Holland.

23. Dogruel, F., Dogruel, A. S., \& Yeldan, E. 2003. "Macroeconomics of Turkey's agricultural reforms: an intertemporal computable general equilibrium analysis", Journal of Policy Modeling.

24. Ejaz Qureshi, M., Proctor, W., Young, M. D., \& Wittwer, G. (2012). The Economic Impact of Increased Water Demand in Australia: A Computable General Equilibrium Analysis. Economic Papers: A journal of applied economics and policy, 
31, 87-102. doi:10.1111/j.1759-3441.2011.00160.x.

25. Ettouney, H. M., El-Dessouky, H. T., Faibish, R. S., \& Gowin, P. J. 2002. "Evaluating the Economics of Desalination”, Chem. Eng. Progress, pp. 32-39.

26. Goldin, I., \& Roland-Holst, D. (1995). “Economic Policies for Sustainable Resource Use in Morocco”. In I. Goldin \& L. A. Winters, Economics of Sustainable Development. Cambridge (MA): Cambridge University Press.

27. Gomez, C. M., Tirado, D., \& Rey-Maquiera, J. R. 2004. "Water Exchanges versus Water Works: Insights from a Computable General Equilibrium Model for the Balearic Islands”, Water Resources Research, 40, W10502 10. 1029/2004WR003235.

28. Goodman, D. J. (2000). More Reservoirs or Transfers? A Computable General Equilibrium Analysis of Projected Water Shortages in the Arkansas River Basin. Journal of Agricultural and Resource Economics, 25(2), 698-713.

29. Hardin, G. (1968). 'The tragedy of the commons'. Science, 162, 1243-1248.

30. Hassan, R., \& Thurlow, J. (2011). Macro-micro feedback links of water management in South Africa: CGE analyses of selected policy regimes. Agricultural Economics, 42(2), 235-247.

31. Horridge, J. M., Dixon, P. B., \& Rimmer, M. T. 1993. “Water Pricing and Investment in Melbourne: General Equilibrium Analysis with Uncertain Streamflow", Center of Policy Studies and The Impact Project, Working Paper n IP-63.

32. Horridge, J. M., Madden, J., \& Wittwer, G. (2005). The impact of the 2002-2003 drought on Australia. Journal of Policy Modeling, 27, 285-308.

33. Income, \& Survey, E. 2001, Stats South Africa.

34. Juana, J. S., Strzepek, K. M., \& Kirsten, J. F. (2011). Market efficiency and welfare effects of inter-sectoral water allocation in South Africa. Water Policy, 13(2), 220-231.

35. Labour, F. S. 2005, Stats South Africa.

36. Letsoalo, A., Blignaut, J., de Wet, T., Wit, e, Hess, M., Tol, S., van Heerden, R. S. J., J., 2007. “Triple Dividends of Water Consumption Charges in South Africa", Water Resources Research, 43. W05412.

37. Liu, J., Hertel, T., \& Taheripour, F. 2016. "Analyzing Future Water Scarcity in Computable General Equilibrium Models", Water Economics and Policy, vol 2, №4.

38. Löfgren, H., \& El-Said, M. 2001. “Food subsidies in Egypt: reform options, distribution and welfare”, Food Policy, $n^{\circ} 26$.

39. Mukherjee, N. 1996. "Water and land in South Africa: economywide impacts of reform”. Discussion Paper. vol. 12, International Food Policy Research Institute, Washington D.C.

40. National Water Resource Strategy, 2004. Department of Water Affairs (DWA), South Africa.

41. National Water and Sanitation Master Plan, Annual Report for 2017/18, Department of Water and Sanitation, South Africa.

42. National Water Accounts for South Africa, 2018. South Africa.

43. O'Ryan, R., de Miguel, C. J., Miller, S., Munasinghe. M (2005). Computable general equilibrium model analysis of economywide cross effects of social and environmental policies in Chile. Ecological Economics, 54, 447-472.

44. National Water and Sanitation Master Plan (NWSMP), 2018. Vol. 1, “Call to Action”, version 10.1., 31 October 2018.

45. Ponce, R., Bosello, F., \& Giupponi, C. 2012. "Integrating water resources into computable general equilibrium models a survey", FEEM Working Paper 57, Fondazione Eni Enrico Mattei, Milan.

46. Population, \& Census, 2001. South Africa.

47. Robinson, S., \& Gehlar, C. (1995). Land, Water, Agriculture in Egypt: the Economywide Impact of Policy Reform. Washington D.C: TMD discussion.

48. Rutherford, T. F. 2000. Lecture Notes - Getting Started with CGE Modeling.

http://web.mit.edu/paltsev/www/docs/intro.htm.

Page 20/21 
49. Sánchez Chóliz, J., \& Sarasa, C. 2019. « Uncertainty in Irrigation Technology: Insights from a CGE Approach”. Water $2019,11,617$.

50. Seung, C. K., Harris, T. R., Macdiarmid, T. R., \& Shaw, W. D. 1998. “Economic Impacts of Water Reallocation: a CGE Analysis for the Walker River Basin of Nevada and California", Journal of Regional Analysis and Policy 28(2).

51. Seung, C. K., Harris, T. R., Englin, J. E., \& Noelwah, R. N. Y. (2000). Impacts of Water Reallocation: A Combined Computable General Equilibrium and Recreation Demand Model Approach. The Annals of Regional Science, 34, 473487.

52. Shapiro, C., \& Stiglitz, J. E. (1984), “Equilibrium Unemployment as a Worker Discipline Device”, American Economic Review, $\mathrm{n}^{\circ} 74,433-444$.

53. Social, A., \& Matrix, U. N. 2016. Base year: 2012.

54. Thabet, T. 2003. "Réforme de la politique des prix de l'eau d'irrigation en Tunisie: approche en équilibre general”, Thesis in economics, June 2003, ENSAER (in French).

55. Tirado, D., Gomez, C. M., \& Rey-Maquieira, J. 2003. “Water Transfer vs Water Works: Insights From A Computable General Equilibrium Model for the Balearic Islands”, first draft, January 31.

56. Van Heerden, J. H., Blignaut, J., \& Horridge, M. (2008). Integrated water and economic modelling of the impacts of water market instruments on the South African economy. Ecological Economics, 66(1), 105-116.

57. Walras, L. 1874. Éléments d'économie politique pure ou Théorie de la richesse sociale, L. Corbaz \& co, Lausanne; Guillaumin \& co, Paris; Georg, H., Basel.

58. Water Management Areas in South Africa, 2010. Statistics South Africa.

59. Water Service, \& Tariffs, 2015. Department of Water and Sanitation, South Africa.

60. Yang, H., \& Zehnder, A. J. B. (2002). Water scarcity and food import: a case study for southern Mediterranean countries. World Development, 30(8), 1413-1430.

61. Yang, H., Reichert, P., Abbaspour, K. C., \& Zehnder, A. J. B. 2003. "A water resources threshold and its implications for food security", in: Hoekstra, A.Y. (ed.), Virtual Water Trade: Proceedings of the International Expert Meeting on Virtual Water Trade, Delft, The Netherlands, 12-13 December 2002, pp. 111-116.

62. Zhang, Y., Lu, Y., Zhou, Q., \& Wu, F. 2020. "Optimal water allocation scheme based on trade-offs between economic and ecological water demands in the Heihe River Basin of Northwest China”, Science of The Total Environment, 703, https://doi.org/10.1016/j.scitotenv.2019.134958.

63. Zhou, Y., \& Tol, R. S. J. (2005). Evaluating the costs of desalination and water transport. Water Resources, Res, 41(3), W03003.

\section{Supplementary Files}

This is a list of supplementary files associated with this preprint. Click to download.

- SACGEV6anomynousAppendices.docx 